\title{
Effects of Livestock Grazing on Sediment Production, Edwards Plateau of Texas
}

\author{
G.R. MCCALLA II, W.H. BLACKBURN, AND L.B. MERRILL
}

\section{Abstract}

The influence of short duration grazing (SDG), moderate continuous grazing (MCG), heavy continuous grazing (HCG), and grazing exclusion on sediment production of midgrass and shortgrass-dominated communities was evaluated over 20-month period on the Texas Agricultural Research Station located near Sonora in the Edwards Plateau, Texas. A combination of cattle, sheep, and goats was used in each grazing treatment. Sediment production was consistently less from the midgrass (bunchgrass) than from the shortgrass (sodgrass) community. The HCG pasture was severely overgrazed and resulted in excessive soil loss. The midgrasses in this pasture were destroyed after 26 months of overgrazing. Sediment production from the SDG pasture stocked at double the recommended rate increased during the study period. The SDG pasture, by the end of the study, had lost more sediment from both the midgrass- and shortgrass-dominated communities than the MCG pasture. Sediment loss from the midgrass community in the MCG pasture was consistently low during the study; however, sediment production from the shortgrass community decreased in the MCG pasture. Sediment production from the midgrass community in the non-grazed pasture remained consistently low throughout the study, but the shortgrass community showed a strong decrease in sediment loss during the study.

Historically, grazing has been an integral part of rangelands (Mack and Thompson 1982) and native herbivores have coevolved with grasslands and most shrublands. However, the introduction of domestic livestock increased the potential for adversely impacting rangeland watersheds. Rangelands by their very nature are naturally large contributors of sediment (Branson et al. 1981). Livestock grazing has the potential of altering the amount and kind of vegetation, which in turn potentially alters surface soil hydrologic characteristics (Blackburn et al. 1982). Reductions in the amount of vegetation may increase raindrop impact, decrease soil organic matter and aggregates, increase surface soil crusting, and decrease infiltration rates (Chapman 1933, Branson and Owen 1970, Blackburn 1975, Wood and Blackburn 1981). Altering the kind of vegetation may also increase sediment losses. Sediment production of sagebrush (Artemisia spp.) canopy zones in Nevada was less than that of the adjacent interspace areas (Blackburn 1975). Sediment loss from shortgrass-dominated sites in the Rolling Plains of Texas was greater than from adjacent midgrass or shrub canopy sites. Livestock grazing altered the sediment loss most from the midgrass-dominated areas and had little or no influence on the shrub canopy zones or shortgrass areas (Wood and Blackburn . 1982).

Much interest has been generated by specialized grazing systems and their potentials for decreasing erosion and adding economic benefits to the ranching industry. However, little information is available to support many of the claims concerning specialized grazing systems (Gifford and Hawkins 1978, Blackburn et al. 1982). The purpose of this study was to determine: (1) the influence

\footnotetext{
Authors are graduate research assistant, and professor of watershed management, Range Science Department, Texas A\&M University, College Station 77843; and professor of range science, Texas Agricultural Experiment Station, Sonora 76950.

Published with approval of the Director, Texas Agricultural Experiment Station, as TA-18839.

Manuscript received July 25, 1983
}

of heavy continuous grazing, moderate continuous grazing, short duration grazing, and no grazing on sediment loss, and (2) the variables influencing sediment loss.

\section{Study Area}

Research was conducted on the Texas Agricultural Research Station, located near Sonora in the Edwards Plateau, Texas. The 1,404-ha station lies on the boundary separating Sutton and Edwards counties. Station elevation is approximately $632 \mathrm{~m}$ with an average growing season of 240 days.

The Edwards Plateau is second only to the Trans-Pecos region of Texas in length and frequency of drought (Sprott 1971). Station precipitation varied considerably during the study period (Fig. 1).



Fig. 1. Total monthly precipitation, January 1980 through August 1981, and normal monthly precipitation for Texas Agricultural Experiment Station near Sonora. Texas.

Precipitation was highly variable and poorly distributed $(428 \mathrm{~mm})$ in 1980, especially during the early growing season, while 1981 had above average precipitation ( $556 \mathrm{~mm}$ by August). No precipitation was recorded in July 1981 and the greatest precipitation $(171 \mathrm{~mm})$ occurred in the preceding month, June 1981. Average precipitation for the station is $553 \mathrm{~mm}$ annually (TDWR 1982).

The study site soils are Tarrant silty clays, members of the clayey-skeletal, montmorillonitic, thermic family of Lithic Haplustalls. the slopes are $<3 \%$. Vegetation of the study area at the beginning of this project was characterized by oak mottes and grass-dominated interspaces. The grass interspaces were dominated by either mid- or shortgrasses. Grasses on the study site included common curlymesquite (Hilaria belangeri (Steud.) Nash) the dominant sodgrass, threeawn (Aristida spp.), sideoats grama (Bouteloua curtipendula (Michx.) Torr.) the dominant bunchgrass, Texas wintergrass (Stipa leucotricha Trin. \& Rupr.), bluestems (Andropogon spp., Bothriochloa spp., Schizachyrium spp.), and hairy grama (Bouteloua hirsuta Lag.). Dominant woody plants are live oak (Quercus virginiana Mill. var. virginiana), honey mesquite (Prosopis glandulosa Torr. var. glandulosa (Torr.) 
Cockll.) and ashe juniper (Juniperus asheii Buchh.).

Three grazing regimes: 1) heavy continuously grazing (HCG), 2) moderate continuously grazing (MCG), and 3) short duration grazing (SDG) (14 pasture-1 herd; 4 day graze; 50 day rest period) were studied to evaluate the impacts of livestock grazing on selected hydrologic variables. An adjacent non-grazed pasture was added (March 1980) to evaluate recovery from livestock exclusion. The 3 grazed pastures were 6 ha in size and the non-grazed area was 3.5 ha. The HCG pasture was in low fair range condition at the beginning of the study (January 1980). The MCG, SDG, and non-grazed pastures were in fair to high fair condition (USDA 1972). A combination of cattle, sheep, and goats were used in each grazing treatment approximating the recommended AU ratio of 50:25:25, respectively, used on the Edwards Plateau.

The SDG pasture was under a high-intensity, low-frequency (HILF) (8 pasture-1 herd; 17 day graze: 119 day rest period) grazing system prior to the SDG treatment (March 1978-December 1980). It was continuously grazed at a moderate stocking rate, approximately 8.1 ha/AU/yr, previous to the HILF system. The SDG pasture simulated one pasture of a 14-pasture, one-herd system, with approximately a 4-day and 50-day graze/rest cycle. Stocking rates varied from $3.2 \mathrm{ha} / \mathrm{AU} / \mathrm{yr}$ to $4.9 \mathrm{ha} / \mathrm{AU} / \mathrm{yr}$ because of destocking during the 1980 drought. The moderate continuously grazed pasture was historically grazed at $8.1 \mathrm{ha} / \mathrm{AU} / \mathrm{yr}$.

Stocking rate on the HCG pasture varied in accordance with changes in forage production and livestock breeding season and was grazed most intensively at the beginning of the study. Stocking rate ranged from $0.3 \mathrm{ha} / \mathrm{AU} / \mathrm{yr}$ to $12 \mathrm{ha} / \mathrm{AU} / \mathrm{yr}$. This pasture has been extremely heavily grazed since March 1978, but previously was under MCG.

The non-grazed pasture was fenced in February 1980 to exclude livestock and was first sampled in March 1980. Previous grazing history was MCG. This pasture has a greater slope and stonier and shallower soil than the other pastures in the study. This difference was large enough to prevent direct comparison with the grazed pastures; however, recovery of watershed variables from livestock grazing can be evaluated.

\section{Methods}

\section{Sediment Production}

Sediment production was determined using a drip-type rainfall simulator (Blackburn et al. 1974) on 8, 0.5-m randomly located runoff plots in each vegetation type and treatments for each of the 11 sample dates during 1980 and 1981 . The runoff plots were pre-wet with 120 liters of water using a sprinkler system to remove antecedent soil-water content differences and covered with clear plastic to maintain uniform surface water conditions. After the runoff plots drained to field capacity (approximately $24 \mathrm{hr}$ ), simulated rainfall was applied at a rate of $20.3 \mathrm{~cm} / \mathrm{hr}$ for 0.5 hours. This application rate approximates a storm with a return period of 150 years and was necessary to insure runoff from all plots. Runoff was continuously collected and, at termination of the simulated rainfall event, was thoroughly mixed and a 1-liter subsample was collected. The sediment from each subsample was filtered through a \#1 Whatman filter, dried at $105^{\circ} \mathrm{C}$ for $24 \mathrm{hr}$, weighed, converted to sediment yield in $\mathrm{kg} / \mathrm{ha}$, and used as an index of sheet erosion.

\section{Vegetative Cover, Standing Crop, and Mulch}

The percentage of ground cover by midgrass, shortgrass, and forb foliage, and mulch, rock, and bare ground were determined by ocular estimate on each runoff plot from a gridded sampling quadrat. Grasses, forbs, and standing dead material were clipped to a 2-cm stubble height and mulch was hand-collected from each runoff plot. The herbaceous material was dried at $60^{\circ} \mathrm{C}$ for $48 \mathrm{hrs}$ and weighed.

\section{Soils}

Immediately before each simulated rainfall event, soil bulk density and soil water content adjacent to each runoff plots for depths of 0 to $3 \mathrm{~cm}$ and 5 to $8 \mathrm{~cm}$ were determined by the core method (Black 1965) and the gravimetric method (Gardner 1965), respectively. A soil sample was collected from $0-3 \mathrm{~cm}$ within each plot after the simulated rainfall event and analyzed for organic matter by the Walkley-Black method (Walkley and Black 1934), aggregate stability by the wet sieve method (Kemper and Koch 1965), and texture by the hydrometer method (Bouyoucos 1962). Soil surface roughness within each plot was measured with a relief meter similar to the one described by Kincaid and Williams (1966) but consisting of 10 evenly spaced pins.

\section{Analysis}

Data normality was determined by tests for skewness and kurtosis (Snedecor and Cochran 1971). Values for sediment production and surface roughness were highly skewed requiring $\log _{10}$ transformation of the data sets. Within treatment variation (variation among subplots) was allocated to the residual for testing differences $(P<.05)$ among treatments. Differences between vegetation communities and treatment differences by vegetation community were determined by analysis of variance. Treatment means were separated by Duncan's multiple range test (Steele and Torrie 1980). Simple linear correlation and forward stepwise multiple regression analysis were used to determine degree of association and to identify the most important factors determining sediment production (Draper and Smith 1981).

\section{Sediment Production}

\section{Results and Discussion}

Sediment production was significantly greater from the shortgrass-dominated community than from the midgrass-dominated community for all sample dates except March and May 1980 and July and August 1981 (Fig. 2). The greatest sediment loss occurred

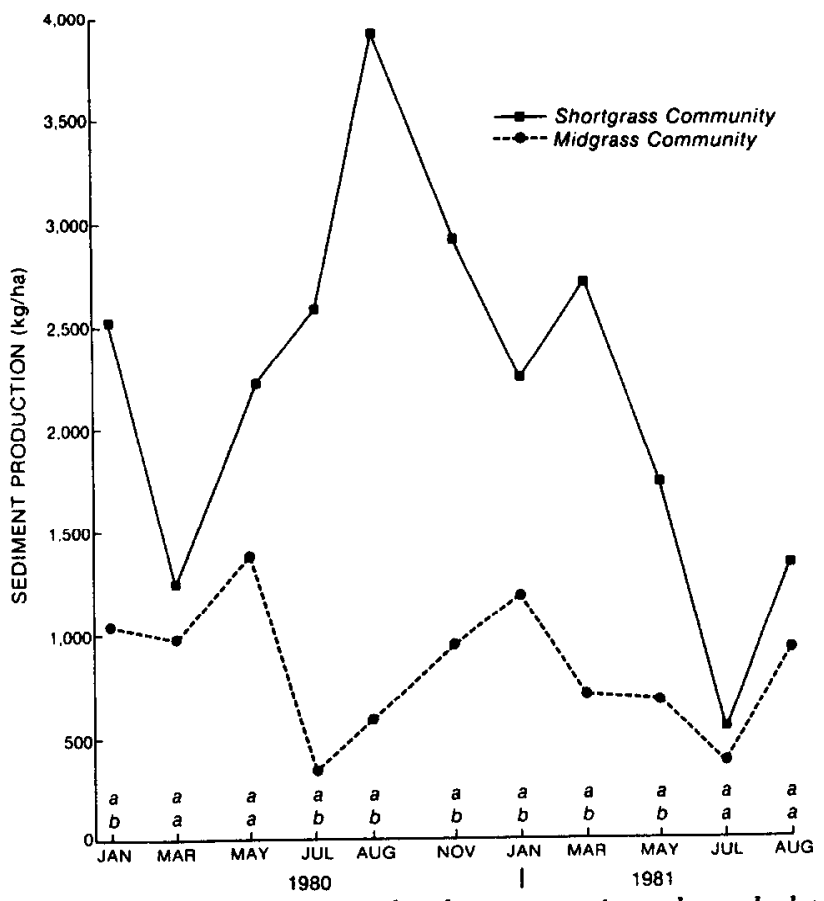

Fig. 2. Mean sediment production by plant community and sample date, Edwards Plateau, Texas. Mean for each sample date with the same letter are not significantly different $(\mathrm{P}<.05)$.

from the midgrass community in May $1980(1,375 \mathrm{~kg} / \mathrm{ha})$ and from the shortgrass community in August $1980(3,874 \mathrm{~kg} / \mathrm{ha})$. Lowest sediment production was from the midgrass community in July $1980(337 \mathrm{~kg} / \mathrm{ha})$ and $1981(363 \mathrm{~kg} / \mathrm{ha})$ and from the shortgrass community in July $1981(524 \mathrm{~kg} / \mathrm{ha})$. The midgrass community showed an annual cyclic pattern with the lowest sediment production occurring in July. The cyclic pattern observed for the short- 
grass community tended to lag the midgrass soil loss pattern by 4 or 5 mo., except in July 1981 where soil loss because of excellent plant growth was low from both communities.

\section{Midgrass Community}

Sediment production of the HCG pasture was significantly greater than the MCG or SDG pastures in January, March and May of 1980 (Fig. 3). Accumulated sediment production through

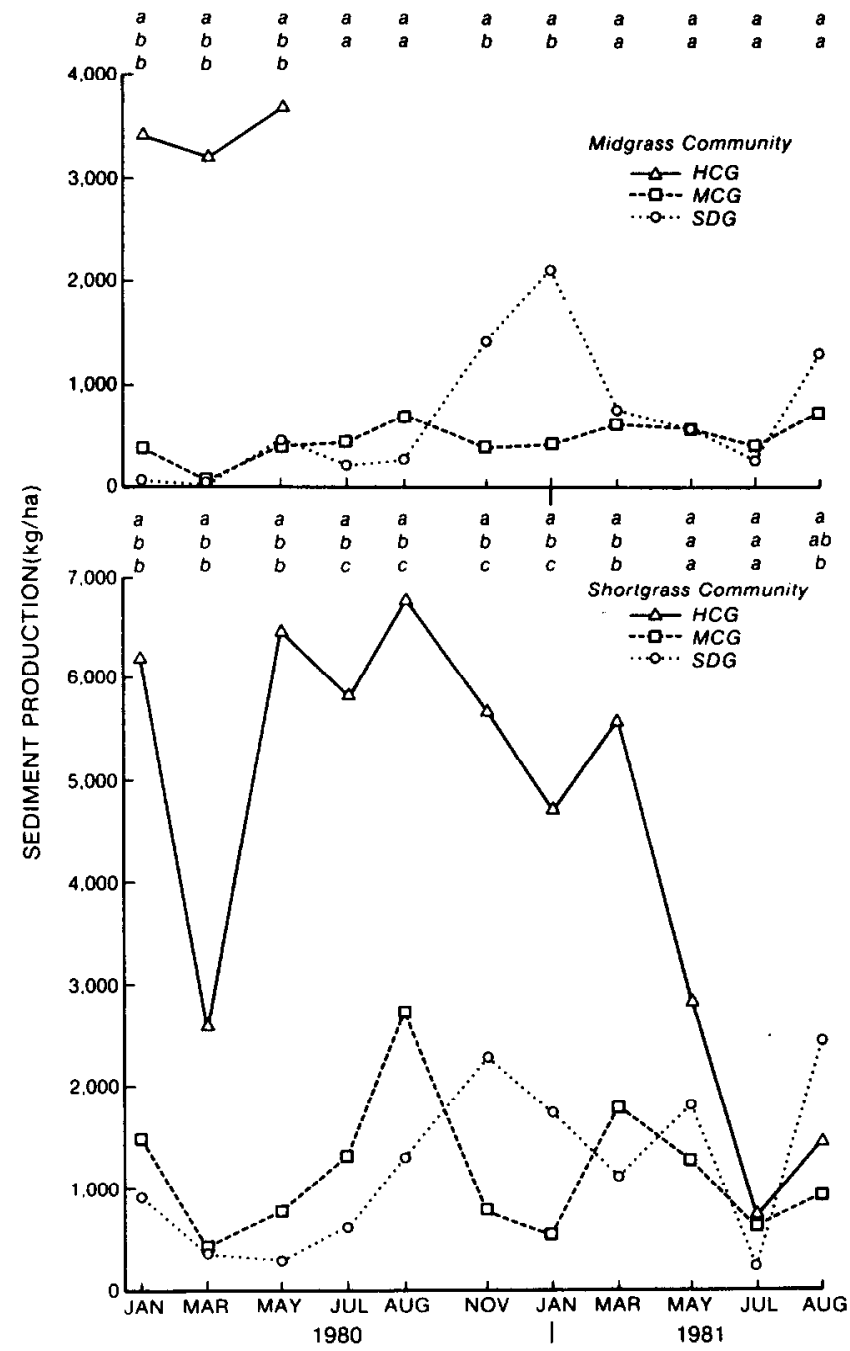

Fig. 3. Mean sediment production for midgrass or shortgrass community by sample date and livestock grazing Edwards Plateau, Texas. Meansfor each sample date with the same lefter are not significantly different $(\mathrm{P}<.05)$. Sampling was discontinued in the midgrass community after May 1980 due to the adverse impact of the heavy stocking rate on bunchgrass.

May was 12 and 18 times greater from the $\mathrm{HCG}$ pasture than from the MCG or SDG pastures (Fig. 4). These large sediment losses from the HCG pasture were primarily a result of the small amount of bunchgrasses. Sampling was discontinued in the midgrass community after May 1980, due to the adverse impact of the heavy stocking rate.

Sediment production from the MCG pasture was consistently low throughout the study (Fig. 3). The lowest sediment loss occurred in March at the beginning of the study and the greatest loss occurred in August 1980 and 1981. Sediment loss from the SDG pasture varied, but was only significantly greater from the MCG pasture in November 1980 and January 1981 . Accumulated sediment production from the MCG pasture was constant throughout the study and was greater than the SDG pasture through August 1980 (Fig. 4). By November 1980, however, more accumulated sediment was lost from the SDG pasture than from the MCG



Fig. 4.Accumulated sediment production' for midgrass or shortgrass plant community by sample data and livestock grazing treatment, Edwards Plateau. Texas. Accumulated soil loss from the HCG pasture was significantly greater $(\mathrm{P}<.05)$. than from the $M C G$ or $S D G$ pastures for each sample date. However, sediment loss was similar from the MCG or SDG pastures. Sampling was discontinued in the midgrass community after May 1980 due to the adverse impact of the heavy stocking rate on bunchgrasses.

pasture. This was primarily the result of the greater soil loss from the SDG pasture than from the MCG pasture during November 1980 and January 1981 , which was attributed to poor growing conditions due to lack of rainfall during this period. Little regrowth occurred during the rest period prior to the November or January sampling dates. Grazing exclusion had little influence on sediment loss from midgrasses (Fig. 5). Sediment loss from the

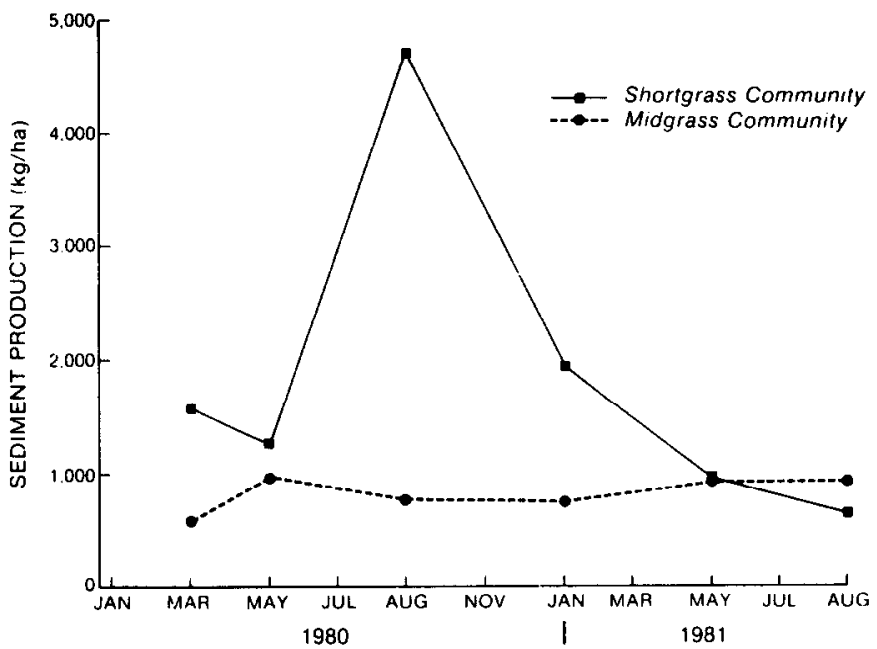

Fig. 5. Mean sediment production for the non-grazed pasture by plant community and sample date, Edwards Plateau, Texas.

non-grazed pasture was consistent throughout the study.

\section{Shortgrass Community}

Sediment production from the HCG pasture was consistently greater than from the SDG or MCG pastures (significant except in May and July of 1981) until August 1981 (Fig. 3). The greatest sediment loss from the HCG pasture was in August 1980 with a general trend, especially after March 1981, toward reduced sediment loss primarily from the reduced stocking rate and improved soil water conditions. Accumulated sediment production was four 
times greater from the HCG pasture at the end of the study than from the MCG or SDG pastures (Fig. 4).

Sediment production from the MCG pasture was variable, with a general trend for reduced sediment production after August 1980. The SDG pasture, however, showed a general trend of increased sediment production after May 1980. More sediment loss occurred from the MCG pasture than from the SDG pasture through August 1980; however, only during July and August was the loss significantly greater. Greater sediment loss occurred from the SDG pasture than from the MCG pasture during November 1980, and January and August 1981. Accumulated sediment production from the MCG pasture was greater than from the SDG pasture through July 1981 (Fig. 4). However, it was not until the last sample date that more sediment had been lost from the SDG pasture than the MCG pasture. This was a result of increased soil loss from the SDG pasture after August 1980. The shortgrass community in the non-grazed pasture showed a strong decrease in sediment production after August 1980 due to the increased plant and mulch cover (Fig. 5). Sediment loss from this pasture was greatest in August 1980 and least at the end of the study.

Sediment production from the SDG pasture increased during the study from both the midgrass and shortgrass communities. Sediment production in the shortgrass community tended to increase from the SDG pasture where trends for the HCG, MCG, and non-grazed pastures were all downward. Sediment production from the midgrass community in the MCG pasture varied little during the study.

\section{Factors Influencing Sediment Production}

Grass standing crop ( $r=0.58)$, midgrass cover $(r=0.53)$, total vegetation cover $(r=0.51)$, surface roughness $(r=0.44)$, bare ground $(r=0.436)$, mulch accumulation $(r=0.43)$ were the variables influencing sediment production the greatest. Midgrass cover accounted for $28 \%$ of the variation in sediment production and was one of the stronger influencing variables. Shortgrass $(r=0.09)$ and forb $(r=0.12)$ cover, however, accounted for less than $2 \%$ of the variation in sediment production and were positively related to sediment loss.

Predictive equations with sediment production as a dependent variable were determined by forward stepwise multiple regression analysis. The independent variables are listed in order of correlation with the highest correlated variable listed first. The multiple regression equation for sediment production is:

sediment production, $y=3.620-0.004 \mathrm{GSC}-0.002 \mathrm{MA}+$ $.013 \mathrm{FC}-0.012 \mathrm{VC}$

Grass standing crop (GSC) was the most important variable followed in order by mulch accumulation (MA), forb cover (FC) and vegetation cover (VC). These variables accounted for $47 \%$ of the variation in sediment production $\left(R^{2}=0.47\right)$ and are all vegetation-related, strongly influenced by midgrasses and are negatively related to sediment production except for forb cover. No surface soil variable occurred in the equation. Forb cover, however, is generally an indication of poor surface soil conditions and/or site abuse. Likewise, midgrasses strongly influence surface roughness, organic matter content and bare ground. Sediment production was influenced more by vegetation variables than by surface soil variables. This may be because of the high organic matter content and well aggregated soil of the study area.

\section{Conclusions}

Sediment production was consistently less from the midgrass (bunchgrasses) than from the shortgrass (sodgrasses) community. A decline in midgrasses, regardless of the cause, results in greater soil loss. The HCG pasture was severely overgrazed and resulted in excessive soil loss. The midgrasses in this pasture were destroyed after 26 months of overgrazing.

Sediment production from the SDG pasture stocked at double the recommended rate increased during the study period. The SDG pasture, by the end of the study, had lost more sediment from both the midgrass- and shortgrass-dominated communities than the MCG pasture. The greater soil loss from the SDG pasture occurred primarily during the 1980 drought. Results strongly suggest that if most of the additional carrying capacity with a SDG system cannot be obtained by increasing livestock distribution as a result of fencing and water development, then extreme caution should be used in adjusting stocking rates upward.

Sediment loss from the midgrass community in the MCG pasture was relatively stable during the study; however, sediment loss from the shortgrass community decreased in the MCG pasture. The non-grazed pasture had a large enough site difference to prevent direct comparison with the grazed pastures. Sediment production from the midgrass community after livestock exclusion remained fairly stable throughout the study, but decreased sediment loss occurred in the shortgrass community.

Variables influencing sediment production include grass standing crop, midgrass cover, total vegetation cover, surface roughness, bare ground and mulch accumulation. The most important multiple regression variables were grass standing crop, mulch accumulation, forb cover, and total vegetation cover.

\section{Literature Cited}

Black, C.A. (ed.). 1965. Methods of soil analysis. Amer. Soc. of Agron. Series No. 9. Madison, Wis.

Blackburn, W.H. 1975. Factors influencing infiltration and sediment production of semiarid rangelands in Nevada. Water Resour. Res. 11:929-937.

Blackburn, W.H., R.W. Knight, and M.K. Wood. 1982. Impact of grazing on watersheds: a state of knowledge. Texas Agr. Exp. Sta. Pub. MP-1496.

Blackburn, W.H., R.O. Meeuwig, and C.M. Skau. 1974. A mobile infiltrometer for use on rangeland. J. Range Manage. 27:322-323.

Bouyoucos, G.J. 1962. Hydrometer method improved for making particle size analysis of soil. Agron. J. 54:464-465.

Branson, F.A., and J.B. Owen. 1970. Plant cover, runoff, and sediment yield relationships on Mancos shale in western Colorado. Water Resour. Res. 6:783-790.

Branson, F.A., G.F. Gifford, K.G. Renard, and R.F. Hadley. 1981. Rangeland Hydrology. Kendall/Hunt Pub. Co., Dubuque, Iowa.

Brock, J.H., W.H. Blackburn, and R.H. Haas. 1982. Infiltration and sediment production on a deep hardland range site in north central Texas. J. Range Manage. 35:195-198.

Chapman, H.H. 1933. Influence of overgrazing on erosion and watersheds. Civil Eng. 3:74-78.

Draper, N.R., and H. Smith. 1981. Applied Regression Analysis. John Wiley and Sons, Inc., New York, N.Y.

Gardner, W.H. 1965. Water Content. In:C.A. Black (ed.), Methods of Soil Analysis. Amer. Soc. of Agron. Series No. 9. Madison, Wis.

Gifford, G.F., and R.H. Hawkins. 1978. Hydrologic impact of grazing on infiltration: a critical review. Water Resour. Res. 14:304-313.

Kemper, W.D., and E.J. Koch. 1965. Aggregate stability of soils from the western portions of the U.S. and Canada. USDA Tech. Bull. 1355.

Kincaid, D.R., and G. Williams. 1966. Rainfall effects on soil surface characteristics following range improvements. J. Range Manage. 19:346-351.

Mack, R.N., and J.N. Thompson. 1982. Evolution in steppe with few large hooved mammals. Amer. Natur. 119:757-773.

Snedecor, G.W., and W.G. Cochran. 1971. Statisitical Methods. Iowa State Univ. Press, Ames, Iowa.

Sprott, J.M. 1971. Texas droughts during the 20th century. Chapter 1. Beef cattle management during drought. Texas Agr. Ext. Serv. Publ. B-1 108.

Steele, R.G.D., and J.H. Torrie. 1980. Principles and Procedures of Statistics. McGraw-Hill Book Co., Inc., New York, N.Y.

Texas Department of Water Resources. 1982. Climatic data for Sonora Experiment Station. Mimeo.

United States Department of Agriculture. 1982. Range condition classification. Mimeo.

Walkley, A., and A.I. Black. 1934. An examination of the Deqtjareff method for determining soil organic matter and a proposed modification of the chromic acid titration method. Soil Sci. 37:29-38.

Wood, M.K., and W.H. Blackbum. 1981. Sediment Procution as Influenced by Livestock Grazing in the Texas Rolling Plains. J. Range Manage. 34:228-231. 